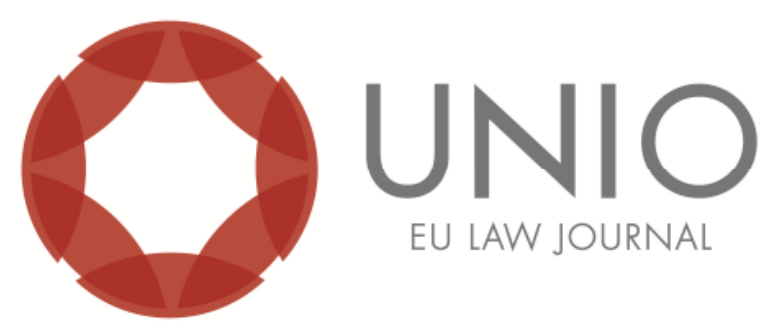

\title{
"Geschichtsmude" - Portugal and the Tiredness of History - How Can Europe Revive its Own Significance?
}

\section{Daniela Cardoso*}

This article is part of UNIO's section for non-reviewed articles. This section aims to publicize activities, projects or initatives of the Center of Studies in European Law, which houses UNIO activities. This article won the 'PRIZE Portugal-Europe 30 years' promoted by the Jacques Delors European Information Centre to celebrate the 30 years of the signature of the Treaty Accession of Portugal to the European Community.

KEYWORDS: citizenship - democracy - culture - memory - responsibility.

* Collaborating Member of the Centre of Studies in European Union Law of University of Minho. 


\section{Introduction}

"Everyone knows that there are a few more things on earth, fair things, and fairer things as compared to the ones that seem to fit into their own philosophy"."

Thirty years after the accession of Portugal to the European Union, Portugal is simultaneously confronted with two dilemmas. The first one refers to the redefinition of its political and economic position within the European cartography which is now carved by one major constraint - the crisis with subject, a crisis in which each and all paradigms are envisaged with exhaustion. A second dilemma concerns the need to understand to what extent the Portuguese democratic tradition can be reconciled with the phenomenon of plurality. European citizenship is, per definition, plural citizenship. This way, it is relevant to analyse the intersections between European identity and national differences being the underlying purpose the need to understand which challenges democracy faces today.

Bringing the present into a critical state and without disregarding asymmetric economic developments there is a pressing need to rethink and redefine the role played by national culture within the European one. Therefore, one is led to understand the values underpinning the integration of Portugal in Europe and its impact on the Portuguese's patrimony, heritage, memory and social awareness.

This essay seeks to explore these questions as the cornerstones of the future, which is hereby depicted as necessarily rooted in a progressive and deeper integration. This integration should be grounded on two keystones: culture and citizenship.

Must it be the case that the revitalization of national politics should be built in parallel with the enhancement of social awareness (a culture of peace)!? Is Portugal ready to attain the dynamics of citizenship, and new discourses about "rights in action" mostly triggered by the presence of Others in States other than the States of their nationality? To what extent do the Portuguese politics of belonging accommodate Rimbaud's "il faut être absolument moderne"? Or the time has come for the Portuguese to fight for the "right to reinvent the language that allows them to reinvent themselves in a transnational scenario, hence to reinvent their relations with society and fight for such recognition"”?

\section{The absence of a paradigm or how to reconcile identity and difference}

When George Steiner wrote his "The idea of Europe" he sought to explore the contemporary European realm inevitably characterised by the lack of debate, constructive criticism and new ideas. Looking back in time, Europe as a continent was beset by a stronger humanist tradition, it was seen as the meeting point for "the peoples" in search for common values, sustainable common principles and a uniform language. This tradition has slowly faded away.

What is left is a wide-reaching melancholy, the type of melancholy that is capable of satisfying nostalgic tourists, newcomers who regard Europe as if it could be comprised in a sophisticated landscape in which old principles have lost their shape in the course of history. This sentiment has a staggering effect both in the European

\footnotetext{
1 A. Ferrer Correia, "Lições de Direito Internacional Privado", Almedina, Coimbra, (2000), p. 121.

2 A. Rimbaud, "A Season in hell” (1873).

3 S. Žižek, "Da Tragédia à Farsa", Relógio d' Água (2009), p. 140.

${ }^{4}$ G. Steiner, A Ideia de Europa, Gradiva 2006, p. 53.
} 
Union and in the Member States. It is precisely at the core of this sentiment that lays the need to thwart such reality. In other words, the need to revive the European culture and strengthen the common principles of citizenship, identity and solidarity.

Located in the periphery of the continent, Portugal has been confronted with different phenomenon over thirty years in the EU. In 1986, the country experienced economic growth and scientific progress which fostered its presence in Europe and nurtured future ambitions. Under criteria of efficiency and efficacy, the economic development would quickly exert an impressive influence on the channels of importation and exportation, on labour, jobs' creation and foreign investment. Automatically, it would generate a strong sense of belonging and inclusion in the social European scenario. Later in time, the country's uncompetitive industrial fabric proved not to be able to adjust to the stirring rhythm of the European market and external demands. The acknowledgment of such reality led to economic losses which hindered both the capacity of the country to compete at the European level and its internal financial sustainability.

This economic scenario paved the way to the acknowledgment of a new dimension, more intimate to "the peoples" of Europe - European citizenship. Undoubtedly, European citizenship is illustrated as a source of rights of its own. These rights encompass the right to vote and stand as a candidate to the elections to the European Parliament or at municipal elections in the Member State where the person resides under the same conditions as nationals of that State; the right to good administration; the right to access documents; the right to access the European Ombudsman; the right of petition; diplomatic and consular protection and freedom of movement and residence and the right to take legislative initiative provided in Article 225 TFEU. The scope of Citizens' rights has been broadened in European secondary law as a product of the incremental approach on the part of the legislature and of the CJEU. Directive 2004/38/EC can be referred as an example $^{5}$. This Directive creates a single regime for the exercise of freedom of movement and residence conferred upon EU citizens and their family members. Also, it does not make the exercise of these rights conditional upon the engagement with cross-border economic activities.

European citizenship is illustrated as an additional layer of rights which are duly safeguarded in the European realm. It is an autonomous status deeply intertwined with the status of national citizenship which complements the European one. This momentum encourages the acknowledgment of the existence of a collective awareness followed by the reinforcement of democracy and democratic legitimacy. National citizens are impelled to play a decisive role in transnational democracy and in the transnational legislative process.

Following the financial collapse, and its endogenous impact on the European and global trade, Portugal's sustainability and material development were seriously undermined. This way the humanist roots in which Europe is embedded were rendered more vulnerable and instable. Consequently, it impaired the transcendent identity and the ethics of citizenship the European Union sought to shape. These elements will be later explored in this article.

Nowadays, European anatomy is punctuated by a wave of nationalist voices and criticism against the model of European governance.

This model of European governance was initially described by Poiares Maduro as firmly embedded in the theory of plural constitutionalism. This means that the

${ }^{5}$ Directive 2004/38/EC on the right of citizens of the Union and their family members to move and reside freely within the territory of the Member States [2004] OJ L 158/77. 
European architecture draws inspiration from national constitutional narratives in which it seeks recognition, legitimacy and authority. One may eventually add another feature: social awareness and reconciliation between European citizens and the European project through a principle of progressive inclusion.

Over these years, this constitutional and national feature of the European Union as such, poses significant challenges.

Firstly, it clearly demonstrates that European normative frameworks are but particular versions of nationals' contexts and structures. The European "demos" and the European "telos" is composed by several "demoi" of the Member States". The European Union was born in the light of the need to revitalize common values! These values concern solidarity, freedom, peace and the cultural and humanist tradition. Secondly, it shows that the financial crisis lived by the European Union reached its pick due to the loss of these common values. This embodies the abovementioned absence of paradigms because all paradigms appear to be stranded in civic deadlocks as if they were submitted to a "planetary civilization". This is the crisis without subject, a crisis mostly sustained by cultural and civic standstills as compared to the financial obstacles. The expression "without subject" means that the epicentre is missing. Being that the case, all States, the European Union and its citizens are called to be confronted with their own definition as such.

Which diagnosis? Or, still in line with philosophical thinking, how can one call Europe and Portugal to explore their own meaning?

With respect to this, the German language is widely recognised by its capacity to capture irreverent meanings under its vocabulary and semantic constructions. When small parts of words are grouped into other words it is possible to come up with new narratives. "Geschichtsmude" refers to this specific talent and is represented in "The Idea of Europe" almost as hosting the tiredness of History. This tiredness is frequently entrenched in gloomy visions concerning the future or its inevitable impossibility which, if taken to the extreme, results in alienation.

A faithful understanding of History is always captured in accordance with the strict limits of the times in which we live. If this time, in particular, does not concede or acknowledge the challenges posed by the cosmopolitan organisation of the European civilization it is time to rethink the culture and the law so that they can both follow and go hand in hand with social evolution.

One of the greatest upcoming challenges for Portugal concerns the need to redignify the Portuguese culture, its heritage, its memory and its language. Portugal can try to find alternatives that escape the hurdles of inevitability and collapse. In order to do that, two different momentums must be analysed.

The first momentum consists of receptiveness towards meaning differences related to economic growth and the ripening process of consolidating European cultural politics. For instance, the nexus nationality-citizenship can be referred as an example. European citizens are, per definition, nationals of Member States and the competence to define the conditions to grant or withdraw nationality rest within the reserved domain of each Member State 7 . This way Portugal simultaneously conveys two complementary identities: one that was given to the country through its historical impulse and another one stemming from the social European tradition.

"S. Besson and A. Utzinger, "European Citizenship across borders" in A. Epiney, M. Haag and A. Heinenmann (eds), Challenging Boundaries: Fetschrift fur Roland Bierber (Schulthess 2007).

${ }^{7}$ Declaration on Nationality of a Member State, annexed to the Final Act of the TEU. Declaration (No 2) on nationality of a Member State, annexed to the Treaty on European Union [1992] OJ C191/98; Convention on Certain Questions Relating to the Conflict of Nationality Law, 13 April 1930, League of Nations, Treaty Series, vol. 179, p. 89, No. 4137. 
However, Portugal has come to a time in which it must urgently redefine its "place of origin", its first and eminent culture. Hence, it must refuse "the freezing of memory or its simple systemic analysis as if reality could be studied in museums made by wax and stereotypes"

It is relevant to understand the current importance of the Portuguese culture and how it can be perceived as an asset and an encouragement for further integration in the upcoming years. The understanding of the cultural foundations of a given State is crucial to redefine a more humane economy. Any economic or financial policy imposed on a State does not have any chances to succeed if it leads to social fragmentation and underestimate its moral dignity, its cultural politics. The future integration of Portugal in Europe cannot be made at the costs of cultural and social indifference and to the employment of other policies which seek immediate and uniform results. On the other hand, the focus must be placed on adaptation and on the Portuguese social awareness, the idea of taking care of what they are fond of. To name a few: its humanitarian education, its vigorous history of wealth' creation through a sober use of resources and international partnerships sustained by a common language (the mother tongue). Until now these vectors have been surrendered by the rigor of the technique.

The intersections between the Portuguese culture and democracy must be brought to light. For instance, a novel is a humble attempt to demonstrate the democratic relation established by the individual and his surrounding society. It belongs to the urgency of the moment and reformulates time's weariness or offers a new meaning to it. The world of ideas always calls for reasoning and the value of reason. Currently, it is the culture that should refuse the lack of memory in which democracies sleep. This scenario encourages the reinvigoration of "the common".

What is at stake is a new relation regarding culture, freedom and inclusion. Its starting point is the idea of autonomy in which art plays an undeniable role. It is fundamental to build democracy because it conveys the values of equity, flexibility, social adaptation, recovery and boldness and safeguards the ethics of inclusion. Portugal needs to seek in art the bits and pieces of understanding and maturity from which the Portuguese society sought to insulate or to replace other temptations.

Over thirty years of the accession of Portugal to Europe, we live in times of democratic restlessness and "a "critical sensitiveness. The politics of belonging and the politics of culture gave away to markets' bustling speed or the "unrest" of the costs stemming from the failures of the system". Due to technical reasons, one survives in the era of technocracy.

In Habermas's "Why Europe needs a Constitution" the author polishes the same unrest of this discourse. There is still anguish and vicissitudes but the future must be faced with authentic humility. Transposing his questions to Portugal - what does the country want? A more civilized country far away from social and intellectual fragmentations? A more civilized Europe? Or a global and civilized Constitution? The truth is that any of the questions requires an answer that must be firstly explored within internal contours; it is always an inner answer.

However, one must shed new light on the ethics of this debate. The future integration of the country depends on the reconfiguration of the channels of understanding and communication between the State and its citizens. The later

\footnotetext{
8 Guilherme d' Oliveira Martins, "Património, Herança e Memoria - a cultura como criação", Gradiva (2009).

9 Jurgen Habermas, "Um Ensaio sobre a Constituição da Europa" (Zur Verfassung Europas: Ein Essay) (2012).
} 
must be incentivised to be part of a collective and social responsibility. They must be brought to the public sphere and exercise their democratic interactions.

The ethics of culture need to be reinvented because they relate to a deeper social integration and welfare capable of encompassing egalitarian relations in more economically sustainable atmospheres.

Europe does not remember its foundations. The answer lies in a principle of citizenship. The exercise and the experience of living citizenship and its democratic interactions is the only way through which memory can be preserved and history redignified since it offers "raison d'etre" to contemporary arguments. The answer to pressing questions of survival and social aspirations stems from the answer given to civic deadlocks.

\section{The ethics of citizenship}

In the first place, one needs to state that the future is a future of further integration of Portugal in the European Union. Any attempt of decoupling is a promise of vulnerability and lack of horizons.

The challenges behind integration are the challenges of citizenship and the way national identities can host and deal with the phenomenon of plurality. Is it not the case that they do it dispassionately? Limitedly?

Citizenship can be defined as an organising principle of political and social life which comprises civic responsibility, active participation in society and political allegiance to the State ${ }^{10}$. It is deeply rooted in the values of equality, membership to the community and collective identity ${ }^{11}$. These values entail a bundle of rights and duties concerning the polity, namely the right to belong to a political community and consequent voting rights and the duties to obey to the laws of the State and to pay taxes ${ }^{12}$.

The phenomenon of migrations embodies new modalities of social and cultural participation and unravels the political traits which are inherent to citizenship. Taking into account the importance of inclusion, to what extent does European Citizenship accommodate the modern political, cultural and social diversity ${ }^{13}$ ?

Migrant communities experience the variable geometry of which senses of belonging and integration are made. This geometry reveals the contradictions between the formal scope of the status accorded to emigrants in the hosting States and the material scope of the rights they own ${ }^{14}$.

In other words, irrespective of the lack of a primary quo status defined by nationality, emigrants or third country nationals possess "quasi-citizenship rights"

\footnotetext{
${ }^{10}$ Marteen Vink and Rainer Bauböck, "Citizenship configurations: analysing the multiple purposes of citizenship regimes in Europe”, Comparative European Politics (2013), Vol. 11, 5, 621-648.

${ }^{11}$ Rainer Baubock, 'Citizenship and National Identities in the European Union', Harvard Jean Monnet Working Paper 97 (1997) p.4; Seyla Benhabib, "Defending a cosmopolitanism without illusions. Reply to my critics", Critical Review of International Social and Political Philosophy ("014), 697-715, DOI: 10/1080/13698230.2014.930784. In a similar position, Linda Bosniak characterizes citizenship as encompassing a legal statute, associated rights, political participation and collective identity. Linda Bosniak, "The Citizen and the Alien: Dilemmas of Contemporary Membership", Princeton: Princeton University studies (2006).

${ }^{12}$ Richard Bellamy, "Evaluating Union Citizenship: belongs, rights and participation within the EU", Citizenship Studies, Vol. 12 No.6 (2008) pp. 597-611.

${ }_{13}$ Declaration on Nationality of a Member State, annexed to the Final Act of the TEU. Declaration (No 2) on nationality of a Member State, annexed to the Treaty on European Union [1992] OJ C191/98; Convention on Certain Questions Relating to the Conflict of Nationality Law, 13 April 1930, League of Nations, Treaty Series, vol. 179, p. 89, No. 4137.

${ }^{14}$ S. Benhabib, "The Rights of Others: Aliens, Residents and Citizens", Cambridge: Cambridge University Press (2004).
} 
lay down in the bundle of rights guaranteed by the Charter of Fundamental Rights of the European Union (Articles 39-46). These rights stem either from the legislative increasing process ${ }^{15}$ or from the political margin of discretion of Member States. In fact, the right to vote and the right to stand as candidate in municipal elections and in elections for the European Parliament under the same conditions as the nationals of Member States, among other rights encompassed by the material scope of European citizenship previously described, are rights from which residents in the States other than the State of nationality can benefit.

In this sense, the nexus nationality-citizenship seems to compete with social progress and social development which acknowledges the exercise and consequent protection of nationality-independent rights.

Nevertheless, transnational movements unravel the pros and cons of the categorical seduction of the premises of citizenship - the right to have rights as defined by Hannah Arendt ${ }^{16}$. This right from which all the rights would stem has never been characterised by Member States and by the European in relation to nonnationals or emigrants. In their case, the status does not precede the rights as its primary legal and political fundament. On the other hand, rights precede the status which illustrates the autonomous character of European citizenship as a source of rights of its own ${ }^{17}$.

Hence, one is confronted with a disaggregation of rights, inclusively political rights. There are new modalities of belonging no longer intertwined with the traditional model imposed by the one of nation-state ${ }^{18}$. This disaggregation shows that democracy needs to be contingent with different modes of social and civic belonging. The underlying question is whether States are or not ready to accommodate such pluralism within their national structures.

If migratory movements encompass the move and the residence in a different State and citizenship refers to the intersection between the individual and his State, there is another nexus that must be brought to light and assessed in countries more exposed to such tendencies, and being Portugal one of them. The new contours embedded in political participation, in which new communities seek to be included, should be explored.

At the international level, despite the fact that the right to emigrate is universally guaranteed as the right to cross-border movement, such rights do not find an immediate correlate meaning on the obligation of the hosting States to accord to newcomers any form of citizenship or daily participation in the State. In other words, migrants are likely to be submitted to national policies which might hinder their integration and the exercise of their rights. The rules behind "mere hospitality" no longer meet the demands of integration and the type of legitimate protection they insist on being accorded to in their hosting State.

\footnotetext{
$\overline{15}$ A Directiva 2004/38/EC [2004] OJ L 158/77 cria um regime singular que concerne o exercício da liberdade de circulação e residência para cidadãos Europeus e os membros das suas famílias, ainda que não oriundos de Estados-Membros.

${ }^{16}$ Hannah Arendt, The Origins of Totalitarianism, Harcourt, Brace \& Co (1951), pp. 294.

17 D. Kochenov, "IUS TRACTUM OF MANY FACES, European citizenship and the difficult relation between status and rights", CJEU, V. 15/No. 2, (2009). 169-237; "EU Citizenship: From an Incipient Form to an Incipient Substance? The Discovery of the Treaty Text”, 37 Eur. L. Rev. 369 (2012); “The Right to Have What Rights? EU Citizenship in Need of Clarification” 19 ELJ (2013); "The Present and the Future of EU Citizenship: A Bird's Eye View of the Legal Debate Jean Monnet Working Papers" (NYU Law School) No.2/12, (2012).

${ }^{18}$ S. Benhabib "Disaggregation of Citizenship Rights" (Parallax 2005). Ver também Winfried Thaa, "Lean Citizenship: The Fading Away of the Political in Transnational Democracy", European Journal of International Relations", (2001) pp.503-525.
} 
Today, states with migratory tradition live under the auspices of a democratic paradox. If citizenship is seen as a powerful instrument of inclusion of any individual in his own polis, rights associated with this experience need to marry a "democratic agency through which their exercise is duly allowed and recognised ${ }^{19}$ ". The tonic must be relocated to political participation entrenched in the right to vote and the right to have a voice. These "democratic interactions" named by Seyla Benhabib underpin the relationships between the State and its citizens, the protection of fundamental rights and offer them a source of institutional legitimacy ${ }^{20}$.

As regards the position of Portugal in this matter, the possession of a legal status is an effective condition that legitimizes the exercise of the rights that sustain a democratic experience in its society. The right to citizenship and its exercise are grounded on a political construction. Inclusion resembles an "irreducible political freedom, otherwise the individual is constantly confronted with an unprotected and bare life being exposed to violence ${ }^{21 "}$.

"Politics and life seem to join the question of citizenship at the same time ${ }^{22}$ ". Does the answer lies in the "depolitization" of citizenship? Or is that the case that the protection of citizens' rights falls under the traps of abstraction and instrumentality leading to the commodification of citizenship? Or should citizenship be diluted into a fundamental right regardless of State' politics?

Under this narrative, it is important to perceive and conceive modes of belonging and modes of non-belonging. Citizenship is never regarded as capturing the presence of one in the world of all but in relation to a State's structure.

Arendt's statement on citizenship as this right to have rights seems to pave the way to a potential apparatus to which Portugal needs to seek the answer.

For instance, if Portugal poses unsurmountable obstacles to the legal regularisation of irregular migrants or to their access to such process including naturalisation, would they be able to claim over themselves the right to belong and the consequent respect for social plurality?

In this context, it is possible to envisage an apparent pre-emptive condition to the exercise of citizenship as such. Drawing on this idea, in principle, everyone has the right to be a citizen and be endowed with that status. In other words, there is a widespread recognition of the need to establish a social and political bond of affiliation between the individual and the State in order to render the channels of communication, civic participation and involvement on State politics more fluid and transparent. This thought triggers a controversial debate on whether there is a fundamental right to citizenship which could be claimed by all and acknowledge and enforceable by the State. The answer to this question encourages the analysis of new sources of political deliberation and legitimacy.

Migrants' communities embody an additional social layer that is placed upon the nation-state paradigm. Taking into account reliable indicators such as the location, time of residence and the strength of bonds of affiliation between the individual and the hosting State, new democratic interactions between the Others and the State in

\footnotetext{
${ }_{19}$ S. Benhabib, The claims of culture. Equality and Diversity in the Global Era, Princeton 2002, Princeton University Press.

${ }^{20}$ G. Delanty, "Models of Citizenship: defining European identity and citizenship", Citizenship Studies, Vol. 1, No. 3 (1997), p. 228.

21 W. Benjamim; Walter Benjamin, 'Zur Kritik der Gewalt', Archiv für Sozialwissenschaft und Sozialpolitik, 47 (1920/21), pp. 809-832. Page numbers in brackets refer to 'Critique of Violence', trans. by Edmund Jephcott, in: One-W ay Street and Other Writings (London: NLB, 1979).

22 J. Butler and Gayatri Chakravorty Spiak, "Who sings the nation state. Language, politics and belonging", Seagful Books (2007).
} 
which they reside are likely to arise. These new democratic interactions can be materialized and shaped through the recognition of a principle of progressive inclusion in the State society.

Portugal being known for its immigration policy can play a pioneering role as regards this challenge. Its underlying promise consists of redefining and recontextualizing the new politics of belonging. Bearing in mind national policies (already consolidated and recognised as reinforcing integration) the development of normative frameworks has to be strenuously aligned with the development of a strong social and civic awareness.

This awareness concerning the reformulation and acceptance of new "modes of belonging" must stem from a vigorous and vibrant European strategy on solidarity, social inclusion and strong agenda on European migration without being discriminatorily punctuated by national interests.

It is possible to conceive such solidarity towards and with the Others in the world of today? Who are the Others? Cannot nationals of the Member States become the Others if they no longer reside in their State of nationality? These questions call for a better integration of citizens being them inside or outside their State. This integration must be carved out by a strong sense of collective and civic awareness and participation in order to generate trust and a more direct or immediate dialogue between citizens, their States - as the interlocutors - and Europe to an ultimate extent. In this sense, the advocacy for a solid inclusion is intertwined with the fight for a fundamental right to the exercise of citizenship

The impulse lies at the characterization of a principle of social organization to be later translated into harmonization of policies on political integration and democratic interactions, it lies at a stronger regularisation of the political situation experience by expats and migrants in their hosting States. These policies must be implemented hand in hand with responsibility, fiscalization or supervision and reinforced neighbouring policies between the States.

To conclude, the social challenge and the enhancement of the Portuguese culture constitute undeniable cornerstones for the upcoming European integration. Portugal needs to redefine its historical and cultural traits. Only the development of internal democratic policies and democracy' delivery mechanisms is capable of consolidating its external position. This must happen in times beset by scientific automatism and technological renovations where any identity and difference are grouped into standardized phenomenon. Or, with Steiner, "In this modern laboratory turned to consumerism in which Europe is diluted, one keeps some selfreferential patterns - "the sainthood of details" that informs our diversity. Nonetheless, we are doomed to our condition of passers-by, lost in transience, in the Minotaur's labyrinth. It is among the tired, confused and divided heirs of Athens and Jerusalem that we can rely on the conviction that it is still possible to mislead the Minotaur and thwart the effort on behalf of Europe ${ }^{23}$."

${ }^{23}$ G. Steiner, A Ideia de Europa, Gradiva 2006, p. 53. 